\title{
Profile of Gallbladder Diseases Diagnosed at Afyon Kocatepe University: A Retrospective Study
}

\section{Afyon Kocatepe Üniversitesi'nde Tanı Konulan Safra Kesesi Hastalıklarının Dağılımı: Bir Retrospektif Çalışma}

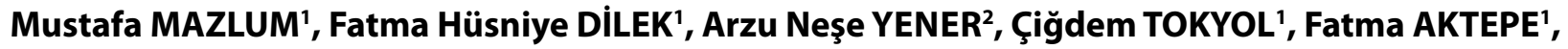 \\ Osman Nuri DiLEK ${ }^{3}$
}

Department of Pathology, ${ }^{1}$ Afyon Kocatepe University, Faculty of Medicine, AFYONKARAHISAR, TURKEY, ${ }^{2}$ Maltepe University, Faculty of Medicine, ISTANBUL, TURKEY, ${ }^{3}$ Department of General Surgery, Sakarya University, Faculty of Medicine, SAKARYA, TURKEY

\begin{abstract}
Objective: Gallbladder is one of the most commonly encountered specimen in a pathology laboratory. A diverse spectrum of diseases affect the biliary system, often presenting with similar clinical signs and symptoms. We aimed to define the profile of gallbladder diseases in our region, and to determine potential correlations between histopathologic features we observed.
\end{abstract}

Material and Method: We reviewed all cholecystectomies processed in Department of Pathology of Afyon Kocatepe University Hospital between January 2000 and March 2008. Gross and histopathologic features of the specimens were reevaluated.

Results: Among 1500 patients; 69.9\% were women and 30.1\% were men. We found out fourteen primary gallbladder carcinomas $(0.93 \%)$ with adenocarcinomas being the most frequent type (78.57\%). The rate of cholelithiasis was found as $89.9 \%$. The most common type of gallstones was mixed cholesterol type gallstones with $67.5 \%$ followed by black pigment and brown pigment types as $23.83 \%$ and $5.89 \%$, respectively. The association of metaplasia with dysplasia and also gallstones were statistically significant $(\mathrm{p}<0.001, \mathrm{p}<0.005)$. The rate of the gallbladder polyps was $2.6 \%$ with the cholesterol polyps being the most common type (56.4\%).

Conclusion: Gallbladder diseases often present with similar clinical signs and symptoms and a surgical pathologist should be alert especially of precancerous lesions. With our results, we also conclude that elderly women with longstanding gallstone disease should undergo elective surgery even when no symptoms are present.

Key Words: Cholelithiasis, Gallbladder diseases, Precancerous conditions, Gallbladder neoplasms, Cholecystectomy

\section{ÖZ}

Amaç: Safra kesesi, bir patoloji laboratuvarında en sık karşılaşılan materyallerdendir. Biliyer sistem hastalıkları genelde benzer klinik özellikler taşır ve bu nedenle klinik olarak ayırtedilemezler. $\mathrm{Bu}$ nedenle bölgemizdeki safra kesesi hastalıklarının dağılımını saptamayı, gözlediğimiz histopatolojik bulguların birbiriyle olası ilişkilerini belirlemeyi amaçladik.

Gereç ve Yöntem: Ocak 2000-Mart 2008 tarihleri arasında Afyon Kocatepe Üniversite Hastanesi Patoloji Anabilim Dalı'nda incelenmiş olan kolesistektomilerin makroskopik ve mikroskopik özelliklerini tekrar gözden geçirdik. Bunun için olguların preparatlarını ve patoloji raporlarını tekrar inceledik.

Bulgular: Toplam 1500 hastanın \%69.9'u kadın, \%30.1'i erkek idi. Serimizde, 14 tane primer safra kesesi karsinomu vardı $(\% 0.93)$ ve en sı tip adenokarsinom idi (78.57\%). Kolelitiazis oranı \%89.9 olarak bulundu. En sık mikst kolesterol taşı izlendi (\%67.5). Bunu siyah ve kahverenkli pigment taşları izlemekteydi (\%23.83 ve \%5.89). Metaplazi ile displazi ve metaplazi ve safra kesesi taşı görülme sıklığ 1 arasında istatistiksel olarak anlamlı ilişki bulundu $(\mathrm{p}<0.001, \mathrm{p}<0.005)$. Safra kesesi polipleri oranı \%2.6 idi ve en sık görülen tip kolesterol polibi idi (56.4\%).

Sonuç: Safra kesesi hastalıkları klinik olarak, birbiriyle benzerlik gösterebileceğinden kolesistektomi materyalini inceleyen patolog, özellikle prekanseröz lezyonlar açısından dikkatli olmalıdır. Bulgularımıza göre; uzun süredir safra kesesi taşı olduğu bilinen özellikle yaşı bayanlara, prekanseröz lezyon gelişme riski nedeniyle, klinik belirti olmasa bile elektif şartlarda kolesistektomi yapılmalıdır.

Anahtar Sözcükler: Kolelitiazis, Safra kesesi hastalıkları, Prekanseröz durumlar, Safra kesesi neoplazmları, Kolesistektomi 


\section{INTRODUCTION}

The gallbladder (GB) is one of the most commonly encountered specimens in a pathology laboratory. A diverse spectrum of diseases affect the biliary system, often presenting with similar clinical signs and symptoms. Although cancer arising in this organ is very rare, a surgical pathologist should be alert especially of precancerous lesions while processing and evaluating the specimen.

In this study, we reviewed all cholecystectomies that were processed at the pathology department of AKU Education Hospital between January 2000 and March 2008. We aimed to define the profile of GB diseases, and to determine possible correlations between histopathologic features.

\section{MATERIAL and METHOD}

One thousand and five hundred consecutive cholecystectomies were included in our study. All patients provided informed consent. We evaluated the patients in two groups as those with or without cancer. All macroscopic descriptions were reviewed and the slides reexamined. The paraffin blocks were recut when needed. The specimens were known to have been processed under standard protocols. At least 2 standard sections were examined for each case. The following gross and histological features were detected by previously determined criteria (1-6): Gross type of gallstones, thickness of the GB wall and other gross descriptions based on the patient's final pathology reports, the type of inflammation, cholesterolosis, polypoid lesions, metaplastic (pyloric and intestinal) and dysplastic changes. Another 14 primary GB carcinomas out of the 1500 materials are reevaluated separately.

The SPSS/PC V3.1 program was used to perform all statistical analysis.

\section{RESULTS}

Overall, 1049 patients were women (69.9\%) whereas $451(30.1 \%)$ were men. The mean age of the patients was $51.94 \pm 14.22$ for women with an age range of $16-97$ and $55.40 \pm 14.07$ for men with an age range of 13-92. The majority of these GBs were removed for symptoms related to cholelithiasis and chronic cholecystitis.

Fourteen patients had primary gallbladder cancer $(0.93 \%)$ whereas 1486 were diagnosed as having benign gallbladder diseases. The rate of cholelithiasis, inflammation, cholesterolosis, polypoid lesions, and some precancerous lesions such as adenoma, antral and intestinal type metaplasia and dysplasia in 1486 patients are listed in Table I.
The rate of cholelithiasis in our series was $89.9 \%$ (1337 patients). Sixty two percent of these patients were females and twenty eight percent were males. We were able to fully identify the type of the gallstones in 797 patients including the 7 cases of cancer with gallstones whereas the gross descriptions were inadequate to define the stone type in 547 patients. We classified the gallstones as pure cholesterol, black and brown pigment stones and mixed cholesterol stones according to previously defined criteria (1). The most common type of gallstone was the mixed cholesterol type (538/797-67.50\%) (Figure 3) followed by the black pigment type (190/797-23.83\%); brown pigment type (47/797-5.89\%) and pure cholesterol type (22/797$2.76 \%)$. We observed cholesterolosis in $13.45 \%$ of the specimens with significant female preponderance (82\%). The great majority of the stones (\%79) were of the mixed cholesterol type as seen in seventy eight stone-type-defined cholesterolosis cases.

We observed metaplasia of either antral or intestinal type in 171 among 1486 nonneoplastic materials (11.50\%) and 164 of these cases also had gallstones (95.9\%). The association of metaplasia with gallstones was significant $(\mathrm{p}<0.005)$. It was also significant that 29 of 30 gallbladders with intestinal metaplasia also had gallstones (96.66\%). On the other hand, we found dysplasia in 24 cases (24/1500-1.60\%). Metaplasia was also observed in 18 of these dysplastic GBs either adjacent to or within the dysplastic epithelium. We found a significant association of metaplasia with dysplasia $(\mathrm{p}<0.001)$. We had 14 primary GB carcinomas in our series (0.93\%). The most common type was adenocarcinoma (11 cases, 78.57\%) (Figure 4) followed by one adenosquamous carcinoma (7.14\%), one squamous cell carcinoma (7.14\%) and one undifferentiated carcinoma (7.14\%). Among the cancerous cases, metaplastic and dysplastic changes adjacent to the malignant tissue were observed in only three $(21.42 \%)$ and five $(35.78 \%)$ cases, respectively.

\section{DISCUSSION}

Gallstones are simply classified on the basis of their gross features as cholesterol stones, pigment stones and as mixed ones (5). Cholesterol stones are single, spheroidal and coarsely nodular and they have a translucent bluish white color (5). Pigment gallstones contain large amounts of pigment material and little cholesterol. They can be divided into black and brown stones according to their colors: Brown stones are brownish yellow, soft and show alternate dark and light layers in cross-section whereas black stones are black in color, hard in consistency and show an amorphous appearance on cross section (7). Cholesterol and black 
Table I: The clinical and pathological features of cases

\begin{tabular}{|c|c|c|c|}
\hline & $\begin{array}{c}\text { Female } \\
\mathrm{n}=1049(\%)\end{array}$ & $\begin{array}{c}\text { Male } \\
\mathrm{n}=451(\%)\end{array}$ & $\begin{array}{c}\text { Total } \\
\mathrm{n}=1500(\%)\end{array}$ \\
\hline \multicolumn{4}{|l|}{ Operation Technique } \\
\hline Laparoscopic & $784(74.7)$ & $261(57.9)$ & $1045(69.7)$ \\
\hline Open & $265(25.3)$ & $190(42.1)$ & $455(30.3)$ \\
\hline \multicolumn{4}{|l|}{ Gallstone Type } \\
\hline Pure cholesterol & $20(1.9)$ & $2(0.4)$ & $22(1.4)$ \\
\hline Mixed cholesterol & $390(37.1)$ & $148(32.8)$ & $538(35.8)$ \\
\hline Black pigment & $138(13.1)$ & $52(11.5)$ & $190(12.6)$ \\
\hline Brown pigment & $32(3)$ & $15(3.3)$ & $47(3.13)$ \\
\hline Not defined & $362(34.5)$ & $185(41)$ & $547(36.4)$ \\
\hline \multicolumn{4}{|l|}{ Thickness of GB Wall } \\
\hline $1-2 \mathrm{~mm}$ & $660(62.9)$ & $239(52.9)$ & $899(59.9)$ \\
\hline$\geq 3 \mathrm{~mm}$ & $253(24.1)$ & $168(37.2)$ & $421(28)$ \\
\hline \multicolumn{4}{|l|}{ Type of Inflammation } \\
\hline Acute & $44(4.19)$ & $47(10.4)$ & $91(6)$ \\
\hline Chronic (excluding subtypes) & $961(91.6)$ & $377(83.5)$ & $1338(89.2)$ \\
\hline Chronic active & $12(1.1)$ & $13(2.8)$ & $25(1.6)$ \\
\hline Eosinophilic & $2(0.1)$ & $4(0.8)$ & $6(0.4)$ \\
\hline Xanthogranulomatous & $4(0.3)$ & $2(0.4)$ & $6(0.7)$ \\
\hline Follicular & $4(0.3)$ & $3(0.6)$ & $7(0.4)$ \\
\hline Cholesterolosis & $164(15.6)$ & $36(7.9)$ & $200(13.3)$ \\
\hline \multicolumn{4}{|l|}{ Metaplasia } \\
\hline Antral type & $103(9.81)$ & $38(8.42)$ & $141(18.23)$ \\
\hline Intestinal type & $11(1.04)$ & $5(1.10)$ & $16(2.14)$ \\
\hline A + I type & $13(1.23)$ & $1(0.22)$ & $14(1.45)$ \\
\hline \multicolumn{4}{|l|}{ Polyp } \\
\hline Cholesterol type & $14(1.3)$ & $8(1.7)$ & $22(1.4)$ \\
\hline Inflammatory type & $1(0.1)$ & $2(0.4)$ & $3(0.2)$ \\
\hline Adenomyoma & $3(0.3)$ & $5(1.1)$ & $8(0.53)$ \\
\hline Hyperplastic type & $3(0.3)$ & $1(0.2)$ & $4(0.3)$ \\
\hline \multicolumn{4}{|l|}{ Adenoma } \\
\hline Tubular adenoma of pyloric type & $2(0.2)$ & $-(0.0)$ & $2(0.1)$ \\
\hline \multicolumn{4}{|l|}{ Dysplasia } \\
\hline Low grade & $14(1.3)$ & $6(1.3)$ & $20(1.3)$ \\
\hline High grade / Carcinoma in situ & $5(0.5)$ & $3(0.6)$ & $8(0.6)$ \\
\hline Carcinoma & $13(0.12)$ & $1(0.02)$ & $14(0.93)$ \\
\hline Total & $1049(69.9)$ & $451(30.1)$ & $1500(100)$ \\
\hline
\end{tabular}

Abbreviations: GB: Gallbladder; A: Antral type metaplasia; I: Intestinal type metaplasia. 
pigment type gallstones form in the GB, whereas brown pigment stones form mainly in the intra or extrahepatic bile ducts (8). It has been generally accepted that women are afflicted more often by GB stone disease than men. The female preponderance may be attributable to multiparity (9) or ingestion of certain drugs such as estrogen and oral contraceptives $(8,10)$. Other suggested risk factors are obesity, a diet rich in cholesterol and saturated fats, intake of hypolipidemic agents, low physical activity (9), increased body mass index, positive family history, and increased age (11).

Pathogenetic mechanisms in the formation of macroscopic gallstone starts with GB hypomotility that results in impaired GB emptying and then leads to bile stasis and subsequent cholesterol precipitation and crystal growth (10).

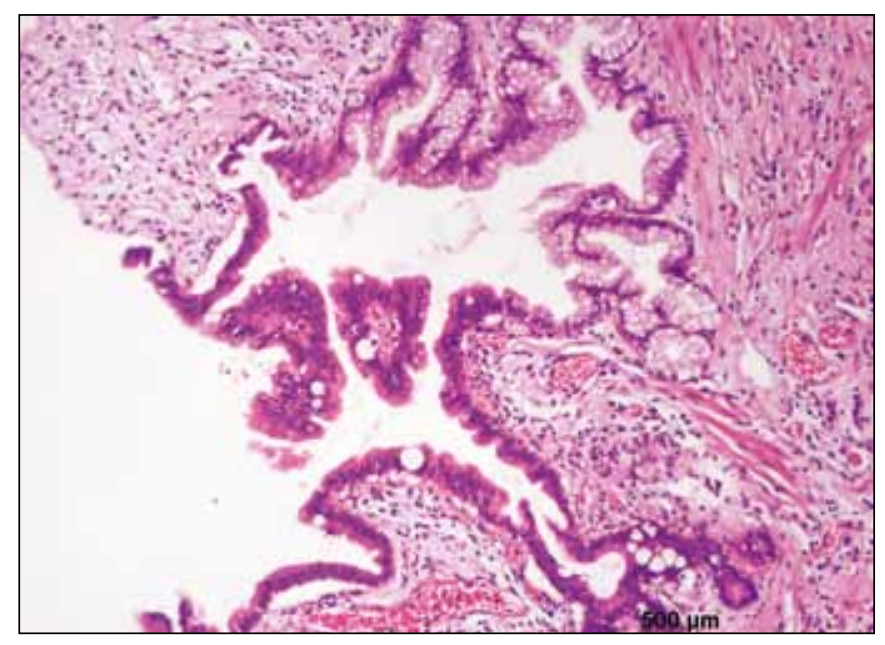

Figure 1: The association of the intestinal metaplasia with dysplasia (H\&E; x200).

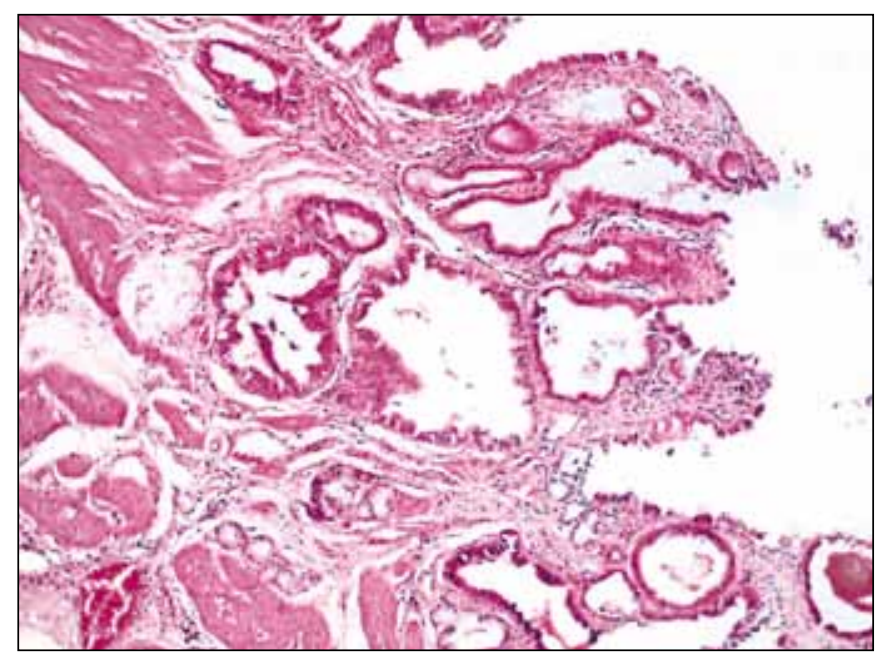

Figure 2: The association of intestinal metaplasia with the cancerous epithelium (H\&E; $\mathrm{x} 400)$.
There are several reports from Turkey on the etiological factors of gallstone formation. Pregnancy (12), iron deficiency anemia (13) and bacterial infections such as $\mathrm{H}$. pylori were suggested to have possible roles in the formation of gallstones (14). Okumuşoğlu et al (15) reported in their series that cholesterol stones are almost three times as frequent as other types of stones and concluded that this might be related to the dietary habits of Turkish people. Similar studies revealed that cholesterol stones tend to occur more frequently in urban populations who have a western-style diet containing more refined sugar, protein and saturated fat whereas pigment stones tend to occur more frequently in rural populations who eat a more traditional Oriental diet high in carbohydrates and fiber and low in protein and fat $(7,8,10,16)$. In our study, the most common type of gallstone was cholesterol-type gallstones

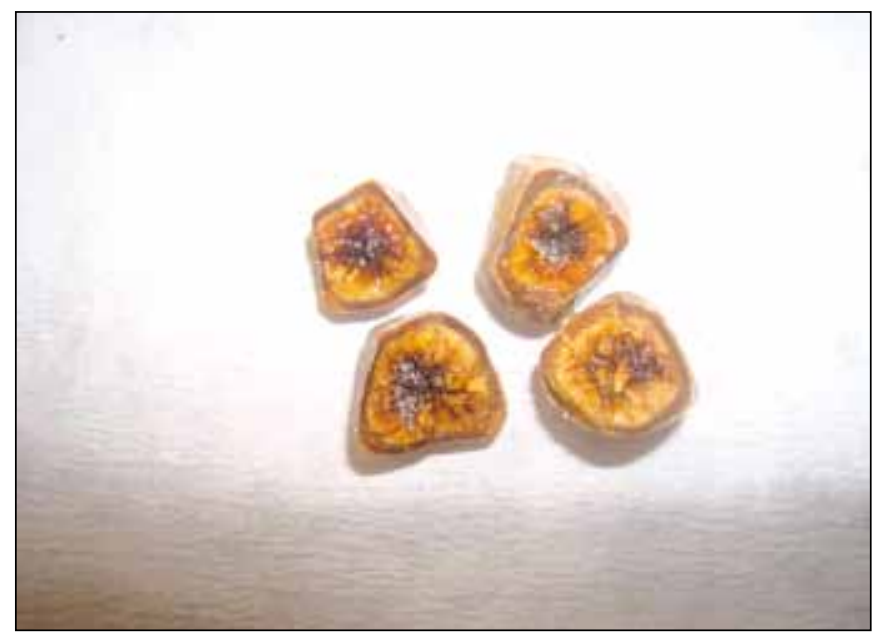

Figure 3: Mixed cholesterol type gallstones were the most common type of gallstones in our series.

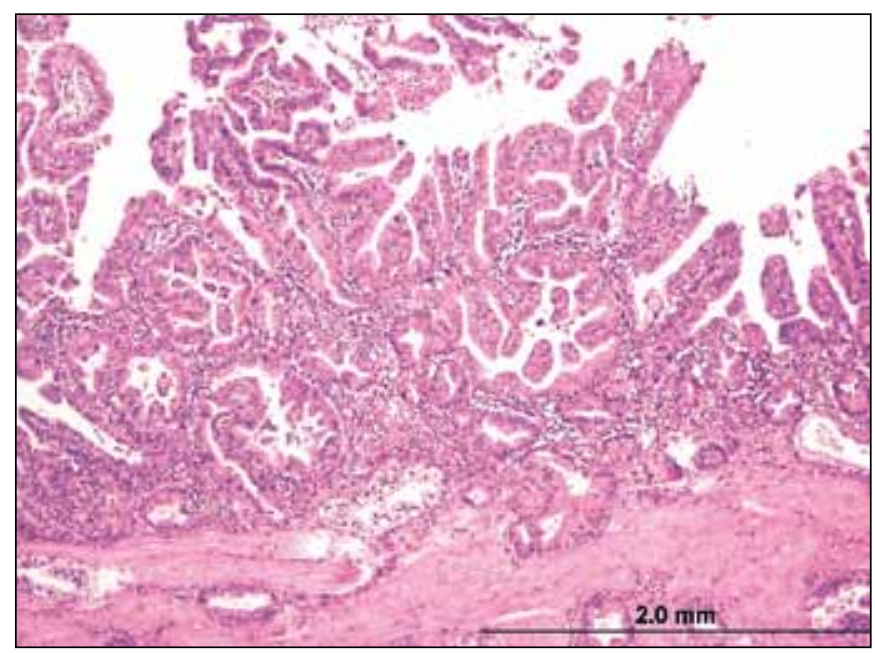

Figure 4: Adenocarcinoma of the gallbladder (H\&E; x100). 
Table II: The most common types of polypoid lesions in the gallbladder (including cancerous cases) in different series

\begin{tabular}{|l|c|c|c|c|c|}
\hline & $\begin{array}{c}\text { Polyp frequency } \\
\text { (histopathological) } \\
\mathrm{n}(\%)\end{array}$ & $\begin{array}{c}\text { Cholesterol } \\
\text { polyp } \\
\mathrm{n}(\%) \ddagger\end{array}$ & $\begin{array}{c}\text { Adenomyoma } \\
\text { (adenomyomatous } \\
\text { hyperplasia) } \\
\mathrm{n}(\%) \ddagger\end{array}$ & $\begin{array}{c}\text { Adenoma } \\
\mathrm{n}(\%) \ddagger\end{array}$ & $\begin{array}{c}\text { Cancer } \\
\mathrm{n}(\%) \ddagger\end{array}$ \\
\hline Huang et al (22) (Taiwan) & $143(* *)$ & $106(74)$ & $10(6.99)$ & $15(10.4)$ & $6(4.19)$ \\
\hline Roa et al (3) (Chile) & $219(1.02)$ & $54(24.6)$ & $15(6.84)$ & $33(15)$ & $-^{*}$ \\
\hline Escalona et al (23) (Chile) & $94(* *)$ & $70.2(66)$ & $2(2.23)$ & $4(4.25)$ & $1(1.06) \dagger$ \\
\hline Terzi et al (17) (Turkey) & $100(1.3)$ & $39(39)$ & $15(15)$ & $20(20)$ & $26(26)$ \\
\hline Ylldirım et al (21) (Turkey) & $17(2.3)$ & $14(82.3)$ & $0(0.0)$ & $2(11.7)$ & $1(5.88)$ \\
\hline Our series (Turkey) & $39(2.6)$ & $22(56.4)$ & $8(20.5)$ & $2(5.12)$ & $2(14.2)$ \\
\hline
\end{tabular}

${ }^{*} 8$ adenomas out of 219 (3.6\%) GB polyps were associated with malignancy, but the number of polypoid GB carcinoma is not given.

$* *$ The total number of the cholecystectomies in their series is not given.

$\dagger 1$ case of carcinoma in situ within an adenoma is reported.

\$ The percentage indicates the frequency of that lesion among the gallbladder polypoid lesions in the given series.

(mixed and pure type together) at a rate of $70.2 \%$. We were expecting to find this result because people consume a high fat and high calorie diet due to livestock marketing in this part of Turkey.

Black stones in the GB consist predominantly of insoluble unconjugated bilirubin polymers and mucin glycoproteins. The main cause of their formation is excessive bilirubin secretion into the bile based upon the increased production of bilirubin, i.e. hemolytic anemia, and previous or current liver damage (1).

The rate of black pigment stones among gallstone patients from Italy and Korea is reported as $5.3 \%$ and $25.2 \%$, respectively $(1,7)$. In our study, the proportion of black pigment stones among total gallstone cases was $12.6 \%$. A sharp distinction of black pigment stones from other stone types is crucial for therapeutic purposes including the determination of the underlying disease such as a hematological or liver disorder.

Brown pigment type stones are formed with the stasisinfection mechanism $(1,8,10)$. Certain infectious agents such as Clonorchis sinensis, Opistochus vivarini or Ascaris $(8,10)$ as well as conditions such as old age, intestinal motor disorders or gastric pathology may be involved in their formation (10). They used to be the predominant type of gallstones in Asia, but are reported to have a decreasing prevalence. This may perhaps be related to multiple factors including the eradication of parasites and westernization of the diet $(7,8)$.

Cetta et al (1) found a brown pigment stone frequency of $5.2 \%$ in their series from Italy. They found that these stones were usually located in the common bile duct and associated with bile infection. Another study on Korean patients revealed that the rate of brown pigment stones in GB and intrahepatic bile duct are $12.1 \%$ and $61.4 \%$, respectively (7). The frequency of brown pigment type stone was only $5.9 \%$ in our study. The design of our study was focused on gallbladder diseases, and gallstones of any other parts of the biliary tract were therefore not evaluated in our study. However, we can still conclude that such parasitic infestations are rare in our region and brown pigment stones are not as commonly encountered as cholesteroltype stones.

Gallbladder polyps (GBP) are simply described as elevated lesions (2) and represent many benign conditions such as cholesterol polyps, adenomyomatous hyperplasia, and adenoma as well as GB carcinoma (17). The detection rate for these lesions has increased with the widespread use of USG in recent years, but it is difficult to define the biologic nature of them radiologically (18). It is suggested that sessile polyps, those are echopenic at USG, with a diameter of greater than $10 \mathrm{~mm}(2,17,19,20)$ and associated with gallstones $(17,21)$ are highly suspicious for malignancy and should be removed, whereas asymptomatic patients with polyps smaller than $10 \mathrm{~mm}$ are subject to follow-up (20). However, Roa et al (3) reported two adenomas less than $5 \mathrm{~mm}$ in length and associated with adenocarcinoma in their series and claimed that polyp size criteria to decide on surgical intervention may be misleading.

Cholesterol polyps are the most frequent $(17,21-23)$ or the second most frequent (3) type of all GBPs. Several reports 
from Turkey reported the rate of GBPs as $1.3 \%-2.3 \%$ with the cholesterol polyp being the most common type $(17,21)$.

We found 39 polyps $(2.6 \%)$ in our series with the most common type being cholesterol polyps (56.4\%) followed by adenomyoma (20.5\%), hyperplastic-type (10.2\%), and inflammatory-type (7.69\%) polyps. We also found that 2 of our cancer cases were also polypoid according to their final pathology report. However, it may be misleading to make a decision on gross polypoid appearance of a solid infiltrative tumor based solely on the pathology report.

Cholesterol polyps are suggested to represent the polypoid variation of cholesterolosis (18). The latter are characterized by mucosal villous hyperplasia with excessive accumulation of cholesterol esters within epithelial macrophages (2). The frequency of cholesterolosis was found $13.33 \%$ in our study. We observed cholesterolosis in all the patients with cholesterol polyps. Their frequency varies in different series as shown in Table II. This might be due to their having a very thin and fragile stalk resulting in its detachment and floating along the bile while evaluating the specimen grossly. The detailed inspection of the wall in the stone containing GB may be difficult and the gallstone moving in the GB may also destroy this stalk.

The epithelial lesions involved in gallbladder carcinogenesis are dysplasia and adenoma, each representing a different carcinogenetic model. Malignant transformation is suggested to develop either through the dysplasiacarcinoma sequence $(24,25)$ or the adenoma-carcinoma sequence (26).

Adenomas are uncommon polypoid lesions simply classified as tubular, papillary or tubulopapillary. They usually arise in the background of normal GB mucosa (27). Based on the morphometrical analysis of both GB adenoma and carcinoma, these lesions were suggested to have malignant potential (26). Kozuka et al (28) suggested that most carcinomas in the GB arise from preexisting adenomas. However, molecular data (29) and morphological findings (24) obtained from completely-mapped early carcinomas support that most GB carcinomas do not arise from adenomas and the adenoma-carcinoma sequence might be a minor pathway in gallbladder tumorigenesis.

We determined 2 adenomas (2/1500-0.13\%) in our study. Both were of the tubular adenoma type and associated with gallstones (mixed cholesterol and black pigment type respectively) as well. We observed severe dysplasia which is reported to frequently exist within these lesions $(3,27)$ in one of them. Neither was associated with malignancy.
The second and more plausible carcinogenetic model is the dysplasia-carcinoma sequence. In this model of carcinogenesis, mucosal damage caused by a stone and subsequent chronic inflammation is thought to be important in the histogenesis of intestinal metaplasia and dysplasia (30) and GB carcinoma as well $(31,32)$. Although the exact relationship between intestinal differentiation and carcinoma is unknown, it is well known that metaplastic epithelium is more susceptible to malignant transformation than the normal one $(4,33)$. It is suggested that cholelithiasis induces the appearance of a stem endodermal cell that, in turn, may differentiate into cells with mature intestinal or gastric phenotypes (34). In this regard, symptomatic gallstones in association with chronic cholecystitis are very likely related to a high incidence of GB carcinoma (10). Pseudopyloric gland metaplasia has less relationship with the basis of carcinogenesis as compared with intestinal metaplasia (35).

We observed either intestinal or gastric type metaplastic cells in 174 out of 1500 cholecystectomies. Among these, $166 / 174(95.40 \%)$ were associated with gallstones whereas 8 of them were not. The association of metaplasia with chronic cholecystitis and with gallstones was statistically significant $(\mathrm{p}<0.05 ; \mathrm{p}<0,05)$. We think that the prolonged mucosal damage by stone(s) causes desquamation and regeneration of mucosal epithelium with subsequent metaplastic changes and especially intestinal metaplasia. On the other hand, dysplasia often develops in metaplastic epithelium (36).

The incidence of dysplasia reported in the literature ranges from 0.4 to $33.8 \%$ and the difference may be explained by a variety of reasons including extent of sampling, varying definitions of precursor lesions, geographic and racial differences in the incidence of GB carcinoma and its precursors (37). Extensive sampling of the proximal, middle and distal segments of the organ with at least 2-3 routine sections for each anatomic part rather than examining a single random section is strongly suggested due to focal and/or patchy distribution of the precursor lesions (33). The latter detects fewer than one third of the precursors compared with the cholecystectomies that are entirely submitted (33).

We found dysplasia in 24 cases $(24 / 1500-1.60 \%)$ in our study. Metaplasia was also observed in 18 out of 24 dysplastic GBs either adjacent to or within the dysplastic epithelium (Figure 1). The association of metaplasia with dysplasia was significant $(\mathrm{p}<0,001)$ and was in accordance with the previously reported data (33). This supports the hypothesis that metaplasia could evolve to dysplasia. We also observed 
intestinal metaplasia in or adjacent to the cancerous epithelium in some instances (Figure 2). However, we could not demonstrate the suggested sequence of intestinal metaplasia-dysplasia-carcinoma probably due to the small size of our cancer series.

In conclusions cholesterol polyps are the most frequent type of gallbladder polypoid lesions. Mixed cholesterol type gallstones are the most frequent type of gallstones in the Afyonkarahisar region where people consumealargeamount of cholesterol and saturated fat. Having demonstrated the association of intestinal metaplasia and GB stones and also of the chronic inflammatory process in the GB, we could conclude that women especially older than 60 years with longstanding gallstone disease should undergo elective surgery even when no symptoms are present. The actual incidence of the precancerous lesions should be obtained by complete mapping of the GB. Larger series are needed to prove the suggested sequence of intestinal metaplasiadysplasia-carcinoma especially in patients with gallstones.

\section{REFERENCES}

1. Cetta F: The role of bacteria in pigment stone disease. Ann Surg 1991, 213:315-326

2. Owen CC, Bilhartz LE: Gallbladder polyps, cholesterolosis, adenomyomatosis, and acute acalculous cholecystitis. Semin Gastrointest Dis 2003, 14:178-188

3. Roa I, de Aretxabala X, Morgan R, Molian R, Araya JC, Roa J, Ibacahe G: Clinicopathological features of gallbladder polyps and adenomas. Rev Med Chil 2004, 132:673-679

4. Mukada T, Andoh N, Matsushiro T: Precancerous lesions of the gallbladder mucosa. Tohoku J Exp Med 1985, 145:387-394.

5. Rosai J: Gallbladder and extrahepatic bile ducts. In Rosai J (Ed): Ackerman's Surgical Pathology. 9th ed., Edinburg, Mosby, 2004, 1035-1060

6. Albores-Saavedra J, Scoazec J, Wittekind C: Carcinoma of the gall bladder and extrahepatic bile ducts. In: Hamilton SR, Aaltonen LA (Eds): WHO classification of tumours. Pathology and genetics of tumours of the digestive system. IARC Press: Lyon, 2000, 206214

7. Kim MH, Lim BC, Myung SJ, Lee SK, Ohrr HC, Kim YT, Roe IH, Kim JH, Chung JB, Kim CD, Shim CS, Yun YB, Min YI, Yang US, Kang JK: Epidemiological study on Korean gallstone disease: a nationwide cooperative study. Dig Dis Sci 1999, 44:1674-1683

8. Shaffer EA: Gallstone disease: Epidemiology of gallbladder stone disease. Best Prac Res Clin Gastroenterol 2006, 20:981-996

9. Devesa F, Ferrando J, Caldentey M, Borghol A, Moreno MJ, Nolasco A, Moncho J, Berenguer J: Cholelithiasic disease and associated factors in a Spanish population. Dig Dis Sci 2001, 46:1424-1436

10. Tazuma S, Kajiyama G: Carcinogenesis of malignant lesions of the gallbladder. The impact of chronic inflammation and gallstones. Langenbecks Arch Surg 2001, 386:224-229
11. Kratzer W, Kächele V, Mason RA, Hill V, Hay B, Haug C, Adler G, Beckh K, Muche R: Gallstone prevalence in Germany: the Ulm gallbladder stone study. Dig Dis Sci 1998, 43:1285-1291

12. Bolukbas FF, Bolukbas C, Horoz M, Ince AT, Uzunkoy A, Ozturk A, Aka N, Demirci F, Inci E, Ovunc O: Risk factors associated with gallstone and biliary sludge formation during pregnancy. J Gastroenterol Hepatol 2006, 21:1150-1153

13. Pamuk GE, Umit H, Harmandar F, Yesil N: Patients with iron deficiency anemia have an increased prevalence of gallstones. Ann Hematol 2009, 88:17-20

14. Abayli B, Colakoglu S, Serin M, Erdogan S, Isiksal YF, Tuncer I, Koksal F, Demiryurek H. Helicobacter pylori in the etiology of cholesterol gallstones. J Clin Gastroenterol 2005, 39:134-137

15. Okumusoglu NT, Korkmaz F, Birchall J: PIXE analysis of gallstones from Turkish patients. Nuc Inst Meth Phys Res 2006, 562:1054-1056

16. Liu JS, Huang CS, Lien HH: Structural analysis of gallstones with thin-section petrographic microscopy: a study of 100 gallstones from Taiwanese patients. J Lab Clin Med 2002, 140:387-390

17. Terzi C, Sokmen S, Seckin S, Albayrak L, Ugurlu M: Polypoid lesions of the gallbladder: report of 100 cases with special reference to operative indications. Surgery 2000, 127:622-627

18. Jørgensen T, Jensen KH: Polyps in the gallbladder. A prevalence study. Scand J Gastroenterol 1990, 25:281-286

19. Aldouri AQ, Malik HZ, Waytt J, Khan S, Ranganathan K, Kummaraganti S, Hamilton W, Dexter S, Menon K, Lodge JP, Prasad KR, Toogood GJ: The risk of gallbladder cancer from polyps in a large multiethnic series. Eur J Surg Oncol 2009, 35: 48-51

20. Csendes A, Burgos AM, Csendes P, Smok Glayds, Rojas J: Late follow-up of polypoid lesions of the gallbladder smaller than 10 mm. Ann Surg 2001, 234:657-660

21. Yildırım M, Erkan N, Yakan S, Boz A, Vardar A: Safra kesesi polipleri: 33 olgunun retrospektif analizi. ADÜ Tip Fakültesi Dergisi 2005, 6:27-30

22. Huang CS, Lien HH, Jeng JY, Huang SH: Role of laparoscopic cholecystectomy in the management of polypoid lesions of the gallbladder. Sur Laparosc Endosc Percutan Tech 2001, 11: 242-247

23. Escalona A, León F, Bellolio F, Pimentel F, Guajardo M, Gennero R, Cruz JP, Viviani P, Ibáñez L: Gallbladder polyps: correlation between ultrasonographic and histopathological findings. Rev Med Chil 2006, 134:1237-1242

24. Roa I, de Aretxabala X, Araya JC, Roa J: Preneoplastic lesions in gallbladder cancer. J Surg Oncol 2006, 93:615-623

25. Stancu M, Caruntu ID, Giusca S, Dobrescu G: Hyperplasia, metaplasia, dysplasia and neoplasia lesions in chronic cholecystitis - a morphologic study. Rom J Morphol Embryol 2007, 48: 335-342

26. Nakajo S, Yamamoto M, Tahara E: Morphometrical analysis of gall-bladder adenoma and adenocarcinoma with reference to histogenesis and adenoma-carcinoma sequence. Virchows Archiv A Pathol Anat Histopathol 1990, 417:49-56

27. Hansel DE, Maitra A, Argani P: Pathology of the gallbladder: a concise review. Cur Diagn Pathol 2004, 10:304-317 
28. Kozuka S, Tsubone N, Yasui A, Hachisuka K: Relation of adenoma to carcinoma in the gallbladder. Cancer 1982, 50: 22262234

29. Yanagisawa N, Mikami T, Saegusa M, Okayasu I: More frequent beta-catenin exon-3 mutations in gallbladder adenomas than in carcinomas indicate different lineages. Cancer Res 2001, 61: $19-22$

30. Martinez-Guzman G, Rosa-Bayon J: Neoplasms and dysplasias of the gallbladder and their relationship with lithiasis. A case control clinicopathological study. Rev Gastroenterol Mex 1998, 63:82-88

31. Kanoh K, Shimura T, Tsutsumi S, Suzuki H, Kashiwabara K, Nakajima T, Kuwano H: Significance of contracted cholecystitis lesions as high risk for gallbladder carcinogenesis. Cancer Lett 2001, 169:7-14

32. Yamamoto M, Nakajo S, Tahara E: Dysplasia of the gallbladder. Its histogenesis and correlation to gallbladder adenocarcinoma. Pathol Res Pract 1989, 185:454-460
33. Duarte I, Llanos O, Domke H, Harz C, Valdivieso V: Metaplasia and precursor lesions of gallbladder carcinoma. Frequency, distribution, and probability of detection in routine histologic samples. Cancer 1993, 72:1878-1884

34. Albores-Saavedra J, Nadji M, Henson DE, Ziegels-Weissman J, Mones JM: Intestinal metaplasia of the gallbladder: a morphological and immunohistochemical study. Hum Pathol 1986, 17:614-620

35. Tomiyama H, Yamagiwa H: Histogenesis of metaplastic and cancerous changes in the gallbladder. Gan No Rinsho 1985, 31:827-832

36. Laitio M: Histogenesis of epithelial neoplasms of human gallbladder I. Dysplasia. Pathol Res Pract 1983, 178:51-56

37. Mukhopadhyay S, Landas SK: Putative precursors of gallbladder dysplasia: a review of 400 routinely resected specimens. Arch Pathol Lab Med 2005, 129:386-390 